\title{
Analysis of the possibility to cover energy demand from renewable sources on the motive power of the heat pump in low-energy building
}

\author{
Maciej Knapik ${ }^{1, *}$ \\ ${ }^{1}$ Institute of Thermal Engineering and Air Protection, Faculty of Environmental Engineering, Cracow \\ University of Technology
}

\begin{abstract}
The article presents the problem of the demand for electricity for the heat pump and an analysis of the coverage of this demand by renewable energy sources such as wind turbines and photovoltaic cells, which generate electricity in low energy buildings. Low-energy and passive constructions are a result of introduction of new ideas in building design process. Their main objective is to achieve a significant reduction in demand for renewable primary energy, necessary to cover the needs of these buildings, mostly related to their heating, ventilation and domestic hot water This article presents the results of numerical analysis and calculations performed in MATLAB software, based on typical meteorological years. The results showed that renewable energy sources, can allow to cover a significant demand for electricity, that is required to power the heat pump it is economically justified.
\end{abstract}

\section{Introduction}

Low energy buildings and buildings modernized in terms of heat are characterized by lower energy demand for heating $[1,2]$. In buildings of this type increased demand of energy for domestic hot water preparation in relation to the total energy demand can be observed. As a result, the proposed solutions allow to further lower energy demand by using the renewable energy sources. Research [3] shows that, to achieve the low demand for non-renewable primary energy, it is also necessary to use renewable energy sources, especially such as solar and wind power. Combining in one building, installations using these two types of renewable energy sources will provide benefits of mutual complementarity, when the energy generation in one of these installations will disappear or will be significantly reduced. In the autumn and winter period, when the possibilities of solar energy are significantly reduced, wind turbines will produce much more energy than photovoltaic cells due to usually occurring windy weather in this time. This situation is changing in the summer period, when the photovoltaic cells produce more energy, due to the longer day and much greater intensity of solar radiation. In the summer months, while the air masses are not moving too quickly, in result, it is observed lower wind speeds and therefore wind turbines produce limited amounts of power.

${ }^{*}$ Corresponding author: maciek.knapik@gmail.com 
Application of the above described installations, which use renewable energy sources, can allow to cover a significant demand for electricity, that is required to power the heat pump [4,5] working for purposes of heating and domestic hot water. In case of excess electricity and the lack of heating needs, this energy can be used to heat the hot water in the tank. The use of heat pump in the above-mentioned system, will reduce the energy demand for primary fuels used to generate electricity.

\section{Heat pump and renewable energy sources}

In order to perform the calculations of electricity demand coverage for heat pump, the MATLAB software was used.

The prepared calculation script is based on typical meteorological years and data received from the manufacturers of heat pumps [6] and wind turbines [7]. The calculation script takes into account the variable energy demand for heating and variable production of renewable energy from photovoltaic cells and wind turbines. In a building with low energy demand, the largest energetic needs are generated by domestic hot water. In the model, a system with tank of water, based on calculation procedure given in Polish standard [8] is analysed. Based on the value of the thermal power $Q_{\text {tank }}$ of the system with tank water - it can be calculated as follows:

$$
Q_{\text {tank }}=1,05 \frac{Q_{\text {without tank }}}{\left[\left(N_{h}-1\right) \Phi\right]}+1
$$

where:

$Q_{\text {without_tank }}$ - thermal power of system without a tank of water, based on the maximum hourly water flow, $\mathrm{kW}$

$N_{h}$ - hourly inequality rate of water consumption,

$\phi-$ the real rate of accumulation.

The analyzed system works according to the scheme presented in Fig.1. Renewable energy sources supply a heat pump with electricity, which provides heating needs of the building. In the summer months, the surplus of energy from renewable energy sources are routed directly to the heater in the domestic hot water.

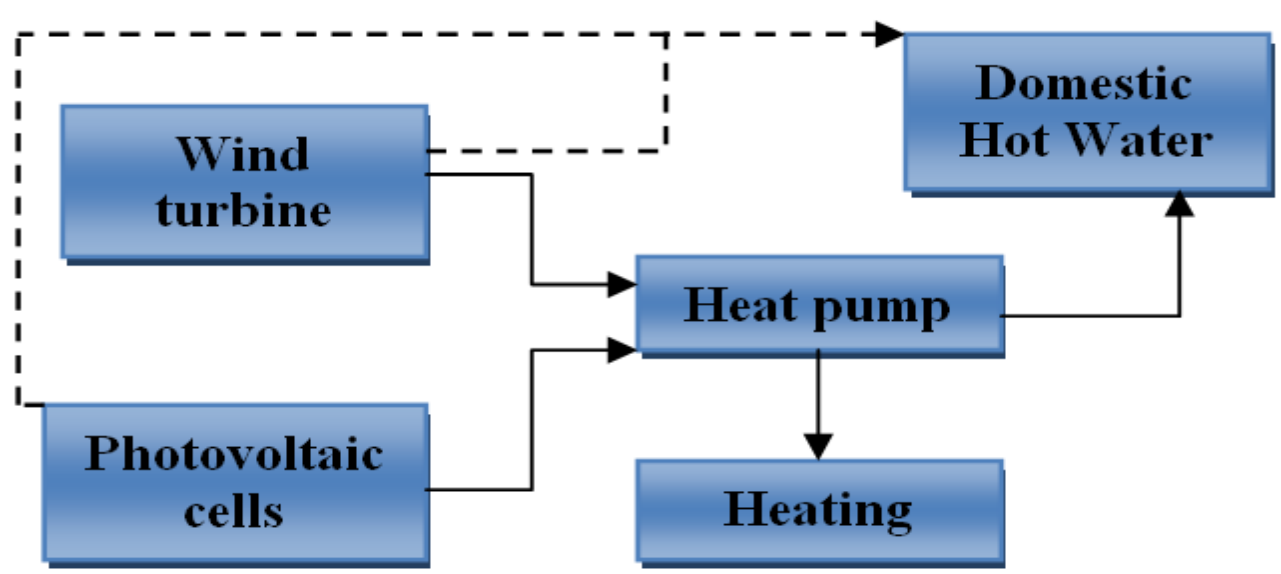

Fig. 1. Scheme of the analyzed system.

To carry out the analysis and calculations it is necessary to adopt a few assumptions - summarized in Table 1. 
Table 1. The assumptions for the analysis and simulation.

\begin{tabular}{|c|c|}
\hline Description & Assumption \\
\hline Building type & $\begin{array}{c}\text { Multifamily, modernized, low } \\
\text { energy building, 18 kW heat losses }\end{array}$ \\
\hline Location & $\begin{array}{c}\text { Ustka, Poland (Polish first climatic } \\
\text { zone[9]) }\end{array}$ \\
\hline Inhabitants & 20 people \\
\hline Hot water tank & 1000 liters \\
\hline Wind turbines & $\begin{array}{c}\text { Selected 4 wind turbines with power } \\
3 \mathrm{~kW} \text { each }\end{array}$ \\
\hline Photovoltaic cells & $\begin{array}{c}\text { Selected 2 photovoltaic cells with } \\
\text { power 300 W each (orientation S45 }\end{array}$ \\
\hline Heat pumps & $\begin{array}{c}\text { Selected 3 heat pumps with power } \\
11 \mathrm{~kW} \text { each }\end{array}$ \\
\hline
\end{tabular}

Fig. 2 presents the relation of turbine's power with wind speed, for wind turbine with a vertical axis of rotation with nominal power of $\mathbf{3} \mathbf{k W}$.

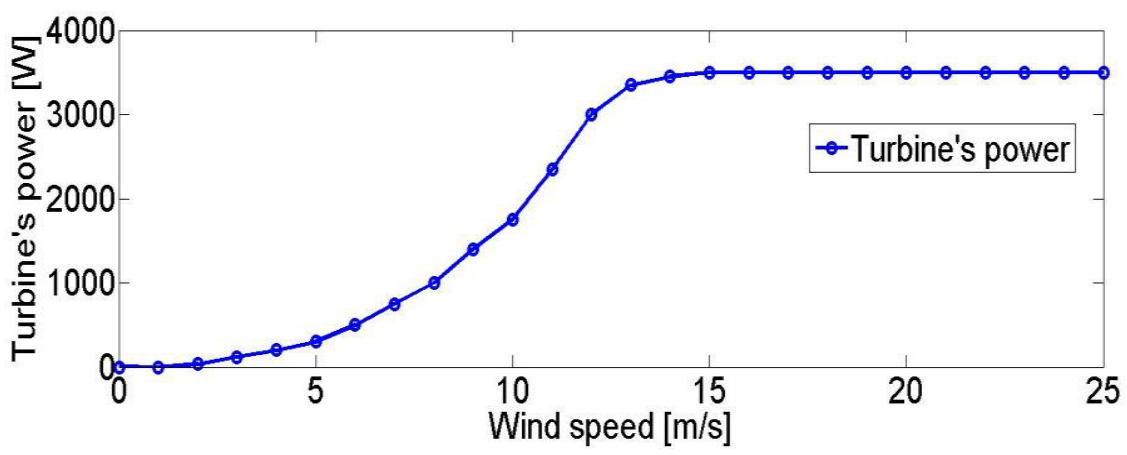

Fig. 2. The power of the wind turbine $(3 \mathrm{~kW})$ at the current wind velocity.

It can be seen that the selected wind turbine starts generating electricity at wind velocity equal to $2 \mathrm{~m} / \mathrm{s}$ and the nominal power is achieved at $12 \mathrm{~m} / \mathrm{s}$.

\section{Results}

As a result of simulation and analysis, was obtained a summary of energy produced from renewable energy sources (wind turbines and photovoltaic cells) in the specified location(according to the accepted assumption). Detailed results of simulation are presented in the Fig.3., which presents the potential electricity generated in within a year. 


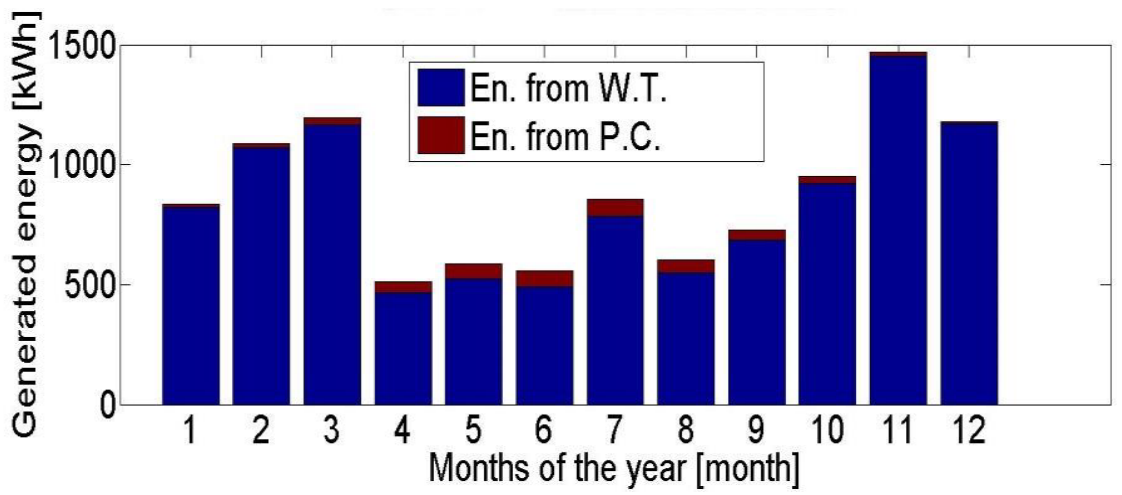

Fig. 3. Summary of energy generated by wind turbines and photovoltaic cells.

A significant difference between the energy produced by wind turbines and photovoltaic results from unequal selection. The selection is the result of adverse weather conditions (solar conditions) for specified location. From an economic point of view, it is reasonable to use more wind turbines. In another location, these conditions may be quite different.

Ustka is located in the Polish first climate zone. This means that, the design outdoor temperature amounts $\mathbf{- 1 6}$ Celsius degrees. Outside temperature within a year is changing continuously. Therefore, it is also changing a temporary demand of heating energy in the heating season of the building. The heating season, this is the time, when building is not heated. In Poland, this period lasts on average from mid-April to October. As a result of the simulation, the detailed results of temporary of thermal load of the building was presented at Fig.4.

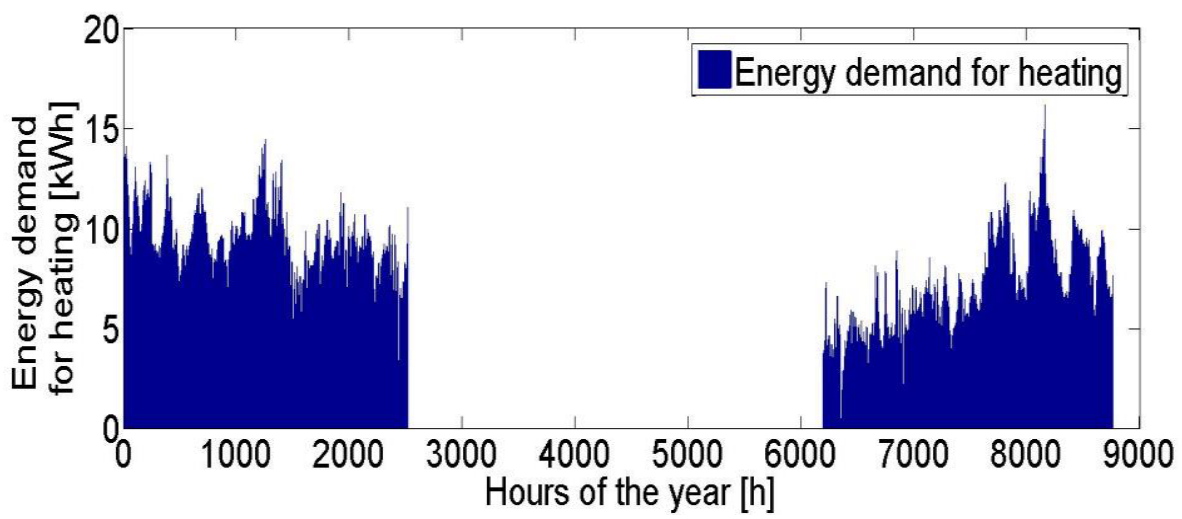

Fig. 4. Summary of energy demand for heating during a year, hour after hour.

Results presented in Fig.4. shows the variability of energy demand for heating purposes. In addition, it can be seen that the heat requirement for heating in a typical meteorological year was close to the predetermined value of the designed thermal load equal to $18 \mathrm{~kW}$. For about half of the heating season, the temporary thermal load of the building oscillates around $50 \%$ of the design thermal load.

The energy efficiency of heat pump type air-water, depends mainly on the outside air temperature. The outside temperature affects on the thermal power of the heat pump and the amount of electricity consumed by it.

The Fig.5. presents the relation of the thermal power of the heat pump and also electrical energy consumed by it, depending on external conditions. 


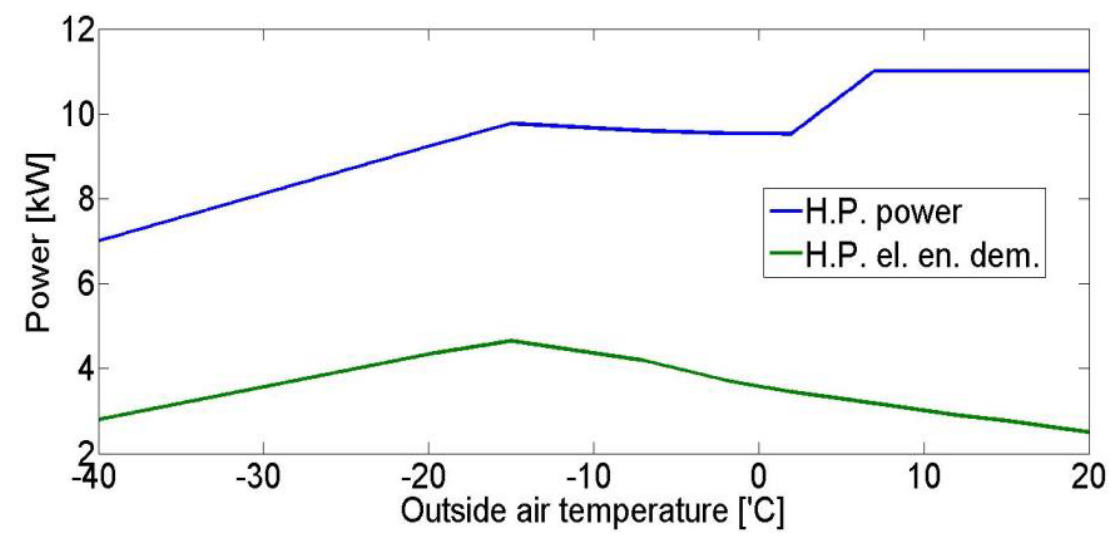

Fig. 5. Heat pump $(11 \mathrm{~kW})$ power and electrical energy demand for heat pump purposes in relation to outside temperature.

In presented simulation, it takes into account the evolving needs for electric energy to motive the heat pump and the thermal power of the selected heat pump. At low temperatures, the efficiency of the heat pump drops significantly, causing a drop in economic efficiency of investment [10].

Based on the data included in the Fig.5. and typical meteorological year was obtained a the following summary of demand for electricity to motive heat pumps in each hour of the year. It is presented on Fig.6.

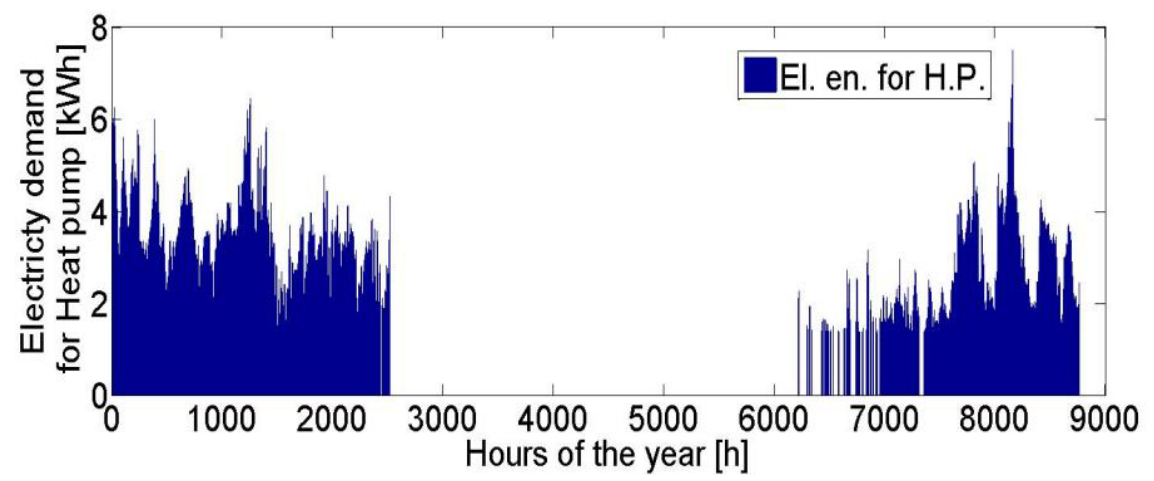

Fig. 6. Heat pumps $(3 \times 11 \mathrm{~kW})$ electrical energy demand for heat pump purposes, hour after hour.

The demand of electricity to motive the heat pump coincides with the demand of thermal energy for heating of the building. After the heating season heat pump does not work and does not consume electricity. After the heating season electricity from renewable energy sources will be used to heat water in the hot water tank by the warmer.

The final result of the analysis and simulation is to present the coverage of energy demand for heat pumps by renewable energy sources. Fig.7. and Fig.8. presents respectively the coverage electricity demand for heat pumps used for heating during the heating season as well as during the summer months, renewable sources of energy are able to cover the energy needs for domestic hot water. 


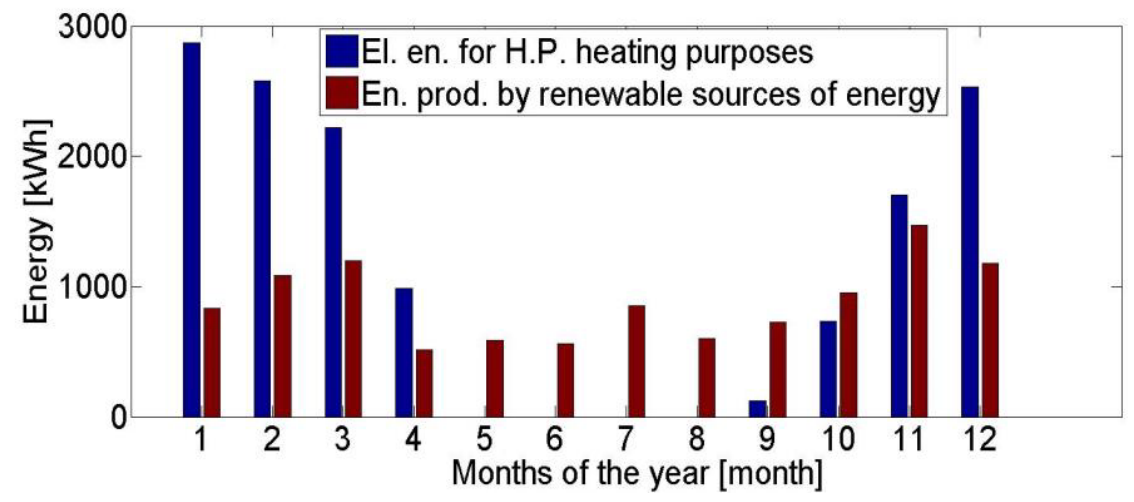

Fig. 7. Comparison of electricity demand for heat pumps with energy produced by renewable sources.

In the analyzed case, renewable energy sources, during the heating season are able to provide about $50 \%$ of the annual energy demand for heating purposes. Surplus of energy from the summer months will be used for domestic hot water preparation. From the other side, in the of low-energy building, higher energy demand is a process of the domestic hot water preparation, which is presented on Fig.8.

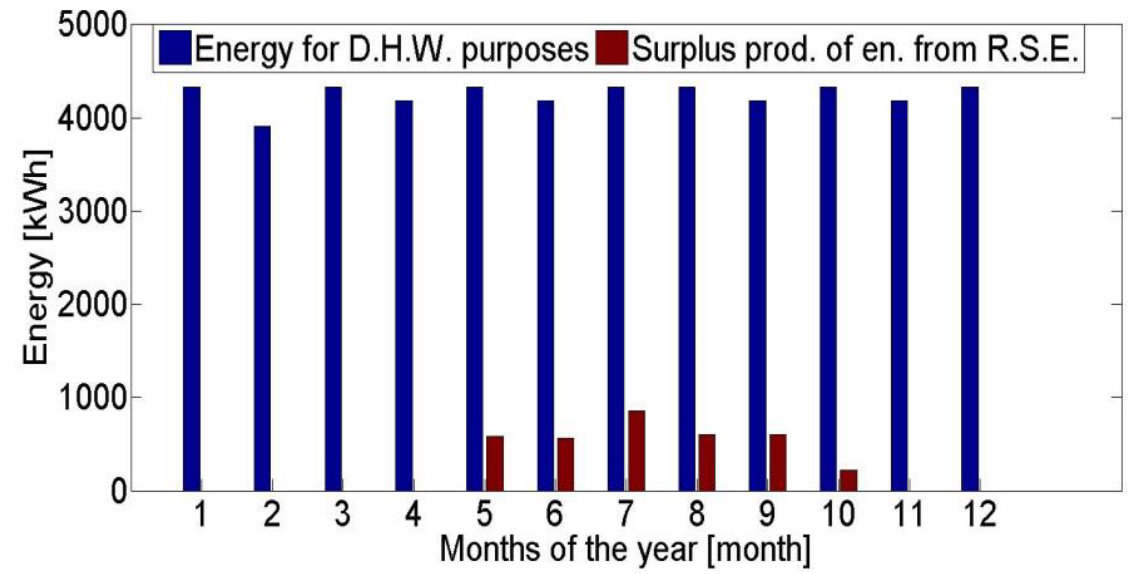

Fig. 8. Comparison of energy demand for domestic hot water purposes with energy produced by renewable energy sources.

By comparing the Fig.7. and Fig.8. can be observed the scale of the participation of energy demand for heating and domestic hot water preparation in the building of a modernized multi-family low energy demand.

The results of analysis and simulation do not present direct economic justification in the particular case.

Visible effects of the simulation can be observed when are compared the operating costs of the analyzed system with a system powered by non-renewable source of energy which is natural gas.

Assuming average prices for electricity, taking into account the day and night electricity tariffs and the average prices of natural gas, has been received a summary of operating costs, which is presented on Fig.9. 


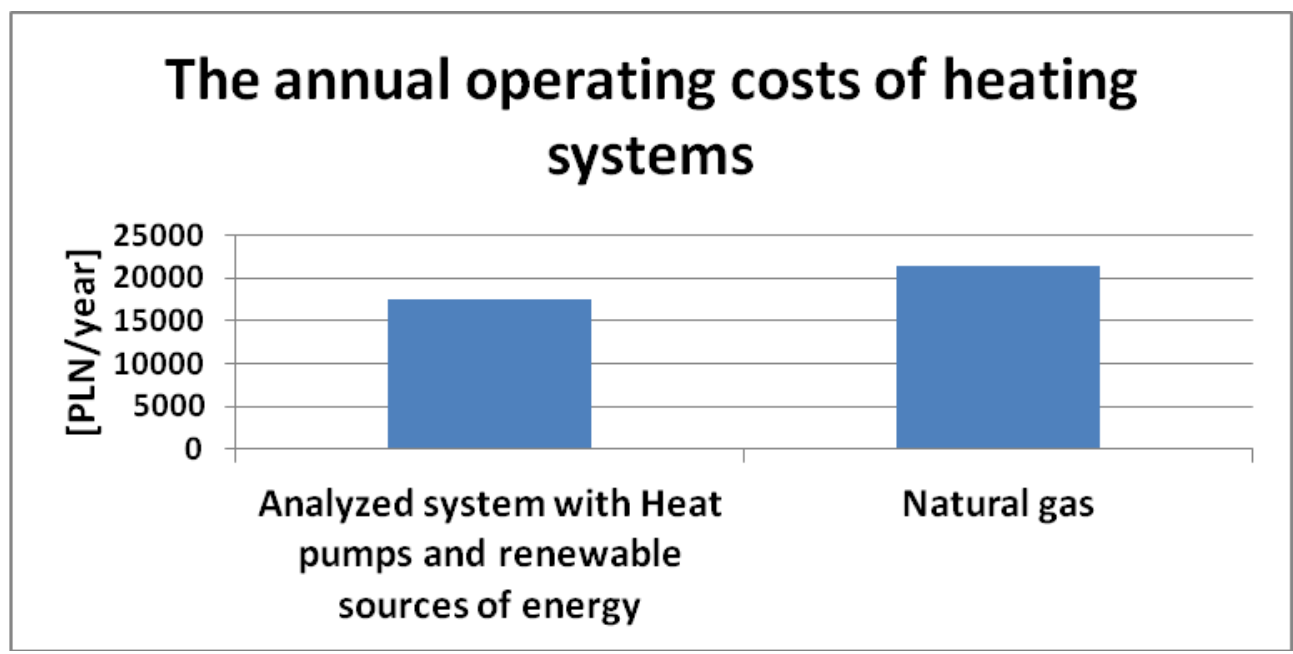

Fig. 9. Comparison of the operating costs of the analyzed system and heating system powered by natural gas.

\section{Conclusions}

The simulation and analysis in MATLAB software allowed to provide the coverage of the energy needs of the building for heating and domestic hot water purposes.

The effectiveness of the various renewable energy sources depends largely on the location and prevailing there advantageous or disadvantageous wind and solar conditions.

Experimental results show that in the low energy buildings about $20 \%$ of heat energy is used for heating domestic hot water. The aim of the study was an analysis of the results of installation cooperation using renewable energy with heat pump, which constitutes the sole source of heat for low energy building. It was also assessed the scope of coverage of the heat demand for heating and domestic hot water energy from renewable sources for the adopted, a typical example of low-energy building and accepted rules of dimensioning cooperating with the pump of solar installation and a small wind turbine. Based on the results of calculations and simulations was rated the coverage of the demand for heating and domestic hot water and was initially rated the economic efficiency of this solution source of energy for low energy building.

The simulation and analysis allow to conclude that, it is preferable to use renewable energy sources which produce electricity to motive heat pumps, which provide the energy needs of the building. The economic effect of analysis can be observed comparing the mentioned system with another system powered by other non-renewable source of energy - natural gas. In an article, for the analysis, it has been deliberately disregarded coal due to significant emissions to the atmosphere and considerable participation in the formation of smog in Polish cities.

\section{References}

1. W. Feist, U. Münzenberg, J. Thumulla, Podstawy budownictwa pasywnego, (2009, ISBN 83-923807-0-3)

2. E. Rylewski, Energia własna, (ISBN 83-917314-2-1)

3. M. Knapik, RI 9 (2016) 
4. K. Wojtas, Polski Instalator 3 (2011)

5. K. Wojtas, Polski Instalator 4 (2011)

6. DAIKIN, technical materials and catalogs

7. Blitzmann, technical materials and catalogs

8. Polish standard, PN-90/B-01706: Instalacje wodociagowe - Wymagania w projektowaniu (1992)

9. Polish standard, PN-EN 12:831: Instalacje ogrzewcze $w$ budynkach - Metoda obliczania projektowego obciążenia cieplnego (2006)

10. prEN 15316-4-2: Heating systems in buildings - Method for calculation of system energy requirements and system efficiencies - Part 4-2: Space heating generation systems, heat pump systems (2008) 